\title{
Drug safety crackdown revs up
}

\section{FDA's strengthened powers to assess drugs already on the market will soon be put to the test.}

It's not easy to quit smoking, but when some people became violent while taking a drug to help them beat their addiction, the US Food and Drug Administration (FDA) took notice. Since its approval in 2006, a popular prescription drug called Chantix (varenicline) has helped smokers curb their cigarette cravings. But the drug has also produced more reports of psychiatric side effects than any other drug on the market, according to the Institute for Safe Medication Practices in Horsham, Pennsylvania.

A paper published on 20 July in The Annals of Pharmacotherapy highlighted 26 instances in which Chantix users became violent in thought or action ${ }^{1}$. In one case, a woman hit her 17-year-old daughter while the girl was driving a car. In another, a man on the drug had his front teeth knocked out after punching a stranger at a bowling alley.

Although every drug bears some risk, those risks can lurk undetected until the drug hits pharmacy shelves - an uncomfortable truth highlighted by the once-popular diabetes drug Avandia (rosiglitazone), which has been linked to heart attacks. In a close decision, an FDA-appointed committee last month voted to allow Avandia to remain on the market with tighter guidelines for how it is prescribed. "Avandia is not an exception or an aberration," says Brian Strom, an epidemiologist at the University of Pennsylvania in Philadelphia. "We'll certainly see more cases like it."

Chantix is one of a growing number of drugs that could soon face similar attention. In 2008, the FDA required Pfizer, the New York-based manufacturer of Chantix, to perform additional safety studies on the drug. In doing so, the agency was flexing new muscle. The Food and Drug Administration Amendments Act,

passed in 2007, gives the agency authority to demand clinical trials even after a drug is on the market. Since then, the FDA has ordered further studies on 132 approved drug applications, some of them well-known pharmaceuticals (see table). The agency also has the power to issue fines if those trials are not completed within an agreed time. All of this suggests that further approved drugs will be thrust into the spotlight over adverse reactions.

But some remain sceptical about whether the act will have its intended effect. "The FDA has a little bit more power, but it has to develop the courage to use

Most drugs are not pulled from the market because they are too risky to be of any use, but rather because they are misused. that power," says Curt Furberg, a physician with the Division of Public Health Sciences at the Wake Forest University School of Medicine in Winston-Salem, North Carolina, and a co-author on the latest Chantix paper ${ }^{1}$. Furberg and others have expressed concern that the FDA's post-marketing watchdogs work under regulators who may be reluctant to question a drug's safety, having approved the drug in the first place.

\section{Hidden risks}

By the time a drug such as Chantix hits the market, it has typically been through clinical trials that can involve several hundred to a few thousand subjects. That's enough to uncover common side effects, or even infrequent events, such as liver failure, that are uncommon in the population at large. But small increases in relatively common ailments can easily slip through. For example, some studies found that Avandia increased the risk of heart attack by $40 \%$ - considered a relatively subtle effect. But given that diabetes patients are

\begin{tabular}{|l|l|l|l|l|l|}
\hline \multicolumn{7}{|l|}{ FIVE EXAMPLES OF PRESCRIBED DRUGS NOW } & UNDER FDA SCRUTINY \\
\hline Drug & Indication & Safety concern & $\mathbf{2 0 0 9}$ sales & Manufacturer & Year approved \\
\hline $\begin{array}{l}\text { Herceptin } \\
\text { (trastuzumab) }\end{array}$ & Breast cancer & Cardiotoxicity & US\$5 billion & Roche & 1998 \\
\hline $\begin{array}{l}\text { Cymbalta } \\
\text { (duloxetine) }\end{array}$ & $\begin{array}{l}\text { Depression } \\
\text { and anxiety }\end{array}$ & Birth defects & $\$ 3$ billion & Eli Lilly & 2007 \\
\hline $\begin{array}{l}\text { Provigil } \\
\text { (modafinil) }\end{array}$ & $\begin{array}{l}\text { Excessive } \\
\text { sleepiness }\end{array}$ & $\begin{array}{l}\text { Severe skin } \\
\text { reaction }\end{array}$ & $\$ 1$ billion & Cephalon & 1998 \\
\hline $\begin{array}{l}\text { Victoza } \\
\text { (liraglutide) }\end{array}$ & $\begin{array}{l}\text { Type } 2 \\
\text { diabetes }\end{array}$ & Thyroid cancer & $\begin{array}{l}\$ 1 \text { billion (2015 } \\
\text { projected) }\end{array}$ & Novo Nordisk & 2010 \\
\hline $\begin{array}{l}\text { Rotarix } \\
\text { (rotavirus } \\
\text { vaccine) }\end{array}$ & Vaccination & $\begin{array}{l}\text { Include } \\
\text { infections and } \\
\text { convulsions }\end{array}$ & $\$ 450$ million & GlaxoSmithKline & 2008 \\
\hline
\end{tabular}

already at high risk of cardiovascular disease, that subtle effect could translate into thousands of heart attacks.

To pick up on those effects, the FDA is also constructing a network called the Sentinel Initiative. Still in early development, the network will eventually link together the nation's largest insurance databases. With those data to hand, FDA watchdogs will increasingly be able to perform studies such as the recent analysis of more than 200,000 Avandia users, performed by FDA epidemiologist David Graham with data collected from patients on Medicare, a governmentsponsored health-insurance programme ${ }^{2}$. Graham's analysis figured prominently in the decision to further restrict Avandia. Large data sets will give regulators more power to identify smaller increases in risk than they have in the past, says Strom. This could, in turn, mark out further drugs for investigation.

But inclusion on the FDA's watch list should not automatically condemn a drug, cautions Steven Nissen, a cardiologist at the Cleveland Clinic in Ohio who published the first metaanalysis of Avandia clinical trials ${ }^{3}$. "Not every drug that raises concern turns out to be a bad drug," says Nissen.

In fact, most drugs are not pulled from the market because they are too risky to be of any use, but rather because they are misused. The painkiller Vioxx (rofecoxib), which was withdrawn from the market in 2004 for causing heart attacks and strokes, was a valuable drug for the few patients who failed to respond to other anti-inflammatory drugs. But thanks to aggressive marketing, the drug was overprescribed, says Strom, and reached patients with a relatively high risk of heart attack.

Such advertising-fuelled haste to embrace new drugs will ensure a steady supply of postmarketing scandals, he says. "It isn't necessarily that the drugs don't have a benefit or have too many risks," he adds. "The issue is that we haven't precisely quantified those risks, and then we start using the drugs too widely." Heidi Ledford

\footnotetext{
1. Moore, T. J. et al. Ann. Pharmacother. doi:10.1345/aph.1P172 (2010).

2. Graham, D. J. et al. J. Am. Med. Assoc. 304, 411-418 (2010)

3. Nissen, S. E. \& Wolski, K. N. Engl. J. Med. 356, 2457-2471 (2007).
} 